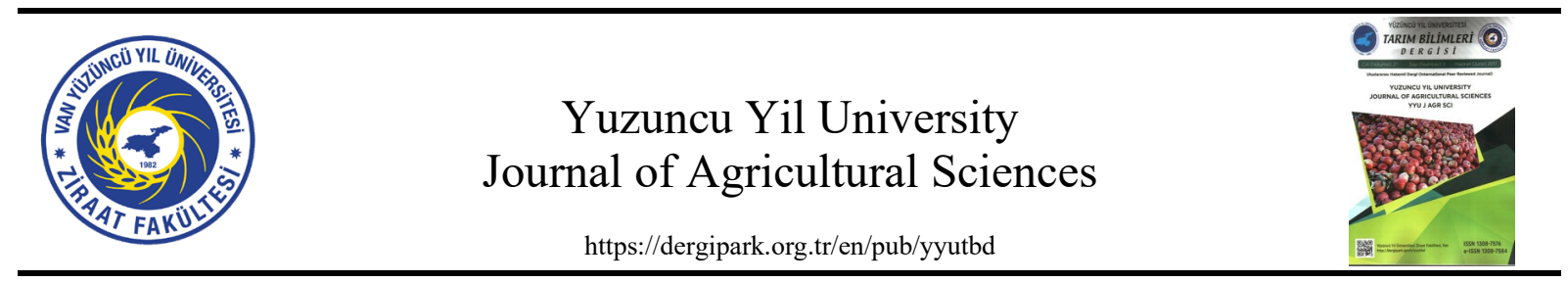

Araştırma Makalesi (Research Article)

\title{
Influence of Internal and External Factors for Youth Agripreneurship Development in Sumatra Region
}

\author{
REFISWAL $^{1}$, Elisa JULIANTI ${ }^{* 2}$, Tavi SUPRIANA ${ }^{3}$, ISKANDARINI ${ }^{4}$ \\ ${ }^{1}$ Universitas Sumatera Utara, Faculty of Agriculture, Doctoral Program of Agricultural Science, Padang Bulan \\ 20155, Medan, Indonesia \\ ${ }^{2}$ Universitas Sumatera Utara, Faculty of Agriculture, Program Study of Food Science and Technology, Padang \\ Bulan 20155, Medan, Indonesia \\ ${ }^{3,4}$ Universitas Sumatera Utara, Faculty of Agriculture, Program Study of Agribusiness, Padang Bulan 20155, \\ Medan, Indonesia \\ ${ }^{1}$ https://orcid.org/0000-0001-6996-7883 ${ }^{2}$ https://orcid.org/0000-0001-7199-3220 ${ }^{3}$ https://orcid.org/0000-0003-2904-1976 \\ ${ }^{4}$ https://orcid.org/0000-0002-8412-8305 \\ *Corresponding author e-mail: elisa1@usu.ac.id
}

\section{Article Info}

Received: 05.12.2020

Accepted: 20.05.2021

Online Published: 15.09 .2021

DOI: 10.29133 /yyutbd.836181

\section{Keywords}

External factors,

Internal factors,

SWOT analysis,

Youth agripreneurship

development.

\begin{abstract}
Development of the agricultural sector is very necessary for efforts and policies to develop agricultural systems that can increase the regeneration of advanced and modern farmers. The research was aimed to analyze internal and external factors of youth agripreneurship development (YAD) in the Sumatra region. This research was conducted in the coordination area of Politeknik Pembangunan Pertanian Medan, which is spread over six provinces in Sumatra, including: Aceh, North Sumatra, West Sumatra, Jambi, South Sumatra, and Bengkulu provinces with all YAD participants in program period from 2017 to 2019. The internal factors include independence and knowledge, while the external factors include capital resources, innovative services, social networks and cooperation. This research was conducted from July until September 2020. The data collection method was conducted by face to face interviews with 230 respondents, field observations, and online interviews and then analyzed using Strength, Weaknesses, Opportunities, Threats (SWOT). The results showed the importance of strategy to improve the YAD through to implementing the diversification strategy. Strategies should be implemented by increasing knowledge and utilization of access to industry-based technology in customer service and product marketing; independence in increasing knowledge and communication skills by attending training; establish more intense cooperation with business partners; and increase promotion to various agencies and companies to attract and establish business cooperation.
\end{abstract}

\section{Sumatra Bölgesinde Genç Tarım Girişimciliğinin Gelişiminde İç ve Dış Faktörlerin Etkisi}

\section{Makale Bilgileri}

Geliş: 05.12.2020

Kabul: 20.05.2021

Online Yayınlanma: 15.09.2021

DOI: 10.29133 yyutbd. 836181
Öz: Gelişmiş ve modern çiftçilerin rejenerasyonunu artırabilecek tarımsal sistemlerin geliştirilmesine yönelik çaba ve politikalar için tarım sektörünün geliştirilmesi çok gereklidir. Araştırma, Sumatra bölgesindeki genç tarım girişimciliği gelişiminin (GTG) iç ve dış faktörlerini analiz etmeyi amaçladı. Bu araştırma, Sumatra'da Aceh, Kuzey Sumatra, Batı Sumatra, Jambi, Güney Sumatra ve Bengkulu illeri olmak üzere altı ilde yayılmış olan Politeknik 


\section{Anahtar Kelimeler}

Dış etkenler,

İç Etkenler,

SWOT analizi,

Genç tarım girişimciliğini geliştirme.
Pembangunan Pertanian Medan'ın koordinasyon alanında tüm GTG katılımcıları ile 2017-2019 yılları arasında gerçekleştirilmiştir. İç faktörler bağımsızlık ve bilgiyi içerirken, dış faktörler sermaye kaynakları, yenilikçi hizmetler, sosyal ağlar ve işbirliğini içermektedir. Bu araştırma Temmuz-Eylül 2020 tarihleri arasında gerçekleştirilmiştir. Veri toplama yöntemi, 230 katılımcı ile yüz yüze görüşmeler, saha gözlemleri ve çevrimiçi görüşmeler yoluyla gerçekleştirilmiş ve ardından güçlü, zayıf yönler, firsatlar ve tehditler (SWOT) kullanılarak analiz edilmiştir. Sonuçlar, çeşitlendirme stratejisinin uygulanması yoluyla YAD'yi iyileştirme stratejisinin önemini gösterdi. Stratejiler, müşteri hizmetleri ve ürün pazarlamasında endüstri tabanlı teknolojiye erişim ve bilgi birikimi artırılarak, eğitime katılarak bilgi ve iletişim becerilerini artırmada bağımsızlığı arttırarak, iş ortakları ile daha yoğun işbirliği kurarak, ticari işbirliğini çekmek ve kurmak için çeşitli kurum ve şirketlere tanıtımı artırarak, uygulanmalıdır.

\section{Introduction}

The agricultural sector is the third sector in Indonesia which has contributed by $12.72 \%$ to GDP in 2019 and has decreased over the last 10 years (Statistics of Indonesia, 2020). The decrease in the contribution of the agricultural sector was influenced by decrease in crop productivity due to reduced of land (Usman and Juliyani, 2018; Santoso, 2015), climatic factors include rainfall, rainy days, and humidity (Tampubolon and Sihombing, 2017; Sihombing et al., 2020), the use of production costs such as subsidized fertilizers and pesticides (Santoso, 2015; Listiani et al., 2019), the capital used (Mamondol, 2017), skills and the total of labor required (Suwarto, 2008; Langit and Ayuningsasi, 2019) and other factors.

The labor is significant and has a positive effect on increasing farming production of citrus (Langit and Ayuningsasi, 2019). Based on data from the Ministry of Agriculture (2018) the Indonesian population working in the agricultural sector is dominated by the food sub-sector of $46.58 \%$, followed by the plantation sub-sector by $30.79 \%$, the livestock sub-sector by $13.47 \%$, and the sub-sector horticulture by $9.16 \%$. In addition, it was also reported that the age of labor in the agricultural sector was still dominated by prime until old ranging from 25 to $>60$ years of $88.89 \%$ and the remaining by $11.11 \%$ at young age ranging from 15 until 24 years and education levels were dominated from primary school until senior high school/vocational school by $98.53 \%$. The low interest of the youth generation in developing the agricultural sector has resulted in the lack of regeneration and has an impact on inhibiting innovation in the agricultural sector as well as has resulted in an imbalance between the population and the total of food available.

The low interest of the youth generation in the agricultural sector in Indonesia can be caused by several factors. Insani et al. (2018) reported that the agricultural system in Indonesia for more than 20 years was directed in a top-down, less place for innovation thus causing stagnation and homogenization of farming cycles. It is causes the young generation to be less interested in working in the agricultural sector. Gulo et al. (2018) also reported that the young generation tends to choose higher wages, agricultural yield is very long and often unsatisfactory. Maga et al. (2016) reported that the level of youth motivation in managing cocoa farming is classified as low, that youth prefer the type of work that earns money quickly compared to cocoa farming.

Efforts to increasing the spirit of young generations to work in the agricultural sector in Indonesia can be conducted by building participation, creating innovation, and the role of the government. Gulo et al. (2018) reported that the surrounding environment show that a lot of people farming with an incomes that is classified as promising to meet the necessities of life with the result that youth generations are motivated for interest in farming, especially in the food sub-sector. Insani et al. (2018) reported that the influence factors of young farmers participation in environmentally friendly agricultural programs include: (1) the characteristics of young farmers with motivation that can provide the value of enthusiasm and always a willingness, opportunity, and ability to participate; (2) innovation of young farmers in environmentally friendly agricultural programs by making natural pesticides then traded and make a profit; (3) environmental factors that affect the level of young farmers participation in environmentally friendly agricultural programs, such as locations in the mountains and government policies to implement environmentally friendly agriculture. 
Therefore, the development of the agricultural sector requires efforts and policies to develop an agricultural system that is able to increase the regeneration of advanced and modern farmers. The government policies and breakthroughs by the Ministry of Agriculture with providing education of entrepreneurship for young generation in agriculture through the Youth Agripreneurship Development (YAD). YAD is an effort to raise awareness, grow, develop, and be independent of the young generation in the field of agricultural entrepreneurship which is manifested in the form of business in the agricultural sector. Young agripreneurship are expected will be able to regenerate farmers in maintaining the availability of food, able to develop more creative and innovative agriculture, able to keep up with technological developments, and able to maintain national economic stability and reduce unemployment by creating jobs. The research was aimed to analyze of internal and external factors for youth agripreneurship development (YAD) in Sumatra region.

\section{Material and Methods}

\subsection{Determination of Location and Sample of YAD}

The location was determined using a purposive method for youth agripreneurship development who received the YAD program in the coordination area of Politeknik Pembangunan Pertanian Medan, which is spread over six provinces in Sumatra region (Aceh, North Sumatra, West Sumatra, Jambi, South Sumatra, and Bengkulu Provinces). The population taken were 542 participants of YAD on the program period from 2017 to 2019 (Table 1).

Table 1. YAD participants from implementing education institutions in the coordination area of Politeknik Pembangunan Pertanian Medan from 2017 to 2019 period

\begin{tabular}{|c|c|c|c|c|c|}
\hline \multirow{2}{*}{ No } & \multirow{2}{*}{ Provinces } & \multirow{2}{*}{ YAD Implementing Education Institutions } & \multicolumn{3}{|c|}{ Participants (Person) } \\
\hline & & & 2017 & 2018 & 2019 \\
\hline \multirow[t]{4}{*}{1} & Aceh & Universitas Syiah Kuala & 2 & 2 & 5 \\
\hline & & VA-AD Saree & 6 & 6 & 8 \\
\hline & & VA-AD Bireuen & - & - & 8 \\
\hline & & VA-AD Kutacane & - & - & 10 \\
\hline \multirow[t]{2}{*}{2} & North Sumatra & Politeknik Pembangunan Pertanian Medan & 155 & 51 & 75 \\
\hline & & Universitas Sumatera Utara & - & 5 & 5 \\
\hline \multirow[t]{4}{*}{3} & West Sumatra & Universitas Andalas & 5 & 6 & 9 \\
\hline & & Politeknik Pertanian Payakumbuh & - & - & 12 \\
\hline & & VA-AD Padang & 9 & 6 & 9 \\
\hline & & VA-AD Padang Mengatas & 10 & 6 & 10 \\
\hline 4 & Jambi Jambi & Universitas Jambi & - & 4 & 3 \\
\hline 5 & South Sumatra & VA-AD Sembawa & - & 10 & 77 \\
\hline \multirow[t]{3}{*}{6} & Bengkulu & Universitas Bengkulu & - & 10 & 9 \\
\hline & & Quantity & 187 & 106 & 249 \\
\hline & & Total & & 542 & \\
\hline
\end{tabular}

Note: VA-AD (Vocational School-Agricultural Development).

The sampling method was conducted by accidental sampling and the number of samples was 230 respondents who were calculated based on the Slovin formula (Sevilla, 2007):

Note:

$$
\mathrm{n}=\frac{\mathrm{N}}{1+N \mathrm{e}^{2}}=\frac{542}{1+(542) \times(0.05)^{2}}=230 \text { respondents }
$$

$\mathrm{n}=$ number of samples

$\mathrm{N}=$ number of populations

$\mathrm{e}=$ acceptable error tolerance $=0.05$ 


\subsection{Data Collection Method}

Data collection was conducted by face to face interviews with participants, observation, and interviews online using google form and phone or email. Data collection were conducted from July to September 2020. Measurement of internal and external factors used in this research could be seen in Table 2 .

Table 2. Measurement of internal and external factors for YAD in Sumatra region

\begin{tabular}{|c|c|c|c|}
\hline Internal factors & Score & Average & Total Score \\
\hline \multicolumn{4}{|l|}{ Answer criteria for the independence variable } \\
\hline Strongly agree & 5 & 3.79 & \multirow{11}{*}{$\begin{array}{c}\text { Independence and } \\
\text { knowledge variables } \\
\text { including strength and the } \\
\text { total score }=1.00\end{array}$} \\
\hline Agree & 4 & & \\
\hline Neutral & 3 & & \\
\hline Disagree & 2 & & \\
\hline Strongly disagree & 1 & & \\
\hline $\begin{array}{l}\text { Answer criteria for the knowledge variable } \\
\text { (training or apprenticeship) }\end{array}$ & & & \\
\hline More than 3 times & 5 & 3.33 & \\
\hline 3 times & 4 & & \\
\hline 2 times & 3 & & \\
\hline Once & 2 & & \\
\hline Never & 1 & & \\
\hline \multicolumn{4}{|l|}{ External factors } \\
\hline \multicolumn{4}{|l|}{ Answer criteria for the capital resources variable } \\
\hline Strongly supported & 5 & 4.20 & \multirow{5}{*}{$\begin{array}{l}\text { Capital resources variable } \\
\text { including opportunities } \\
\text { and the total score was } \\
\qquad 1 / 3=0.33\end{array}$} \\
\hline Supporting & 4 & & \\
\hline Sufficient to supporting & 3 & & \\
\hline Not supporting & 2 & & \\
\hline Strongly not supporting & 1 & & \\
\hline \multicolumn{4}{|l|}{$\begin{array}{l}\text { Answer criteria for the innovative services variable } \\
\text { (audiovisual, internet facilities, access to transportation, } \\
\text { communication services, social media, online markets, } \\
\text { brochures, pamphlets, leaflets, stickers) }\end{array}$} \\
\hline More than or equal to three choices & 5 & 2.40 & \multirow{7}{*}{$\begin{array}{l}\text { Innovative services, social } \\
\text { networks and cooperation } \\
\text { variables including threats } \\
\text { and the total score were } \\
\qquad 2 / 3=0.67\end{array}$} \\
\hline More than or equal to two choices & 3 & & \\
\hline Once choice & 1 & & \\
\hline $\begin{array}{l}\text { Answer criteria for the social networks and cooperation } \\
\text { (agricultural offices, cooperatives, market companies, } \\
\text { wholesalers, online markets) }\end{array}$ & & & \\
\hline More than or equal to three choices & 5 & 2.93 & \\
\hline More than or equal to two choices & 3 & & \\
\hline Once choice & 1 & & \\
\hline
\end{tabular}

After the data from the questionnaire is obtained, the average calculation is conducted for each variable then calculated the weight with the following formula:

$$
\begin{aligned}
& \text { Weight of independence }=\frac{\text { average IV }}{\text { average IV }+ \text { average } \mathrm{KV}} \times \text { total score }(1.00) \\
& \text { Weight of knowledge }=\frac{\text { average } \mathrm{KV}}{\text { average IV + average } \mathrm{KV}} \times \text { total score }(1.00)
\end{aligned}
$$$$
\text { Weight of capital resources }=\text { average CRV } \mathrm{x} \text { total score }(0.33)
$$$$
\text { Weight of innovative services }=\frac{\text { average ISV }}{\text { average ISV }+ \text { average SNCV }} \times \text { total score }(0.67)
$$ 
Note:

Weight of social networks and cooperation $=\frac{\text { average SNCV }}{\text { average ISV }+ \text { average SNCV }} \times$ total score $(0.67)$

$$
\begin{array}{ll}
\text { IV } & \text { = independence variable } \\
\text { KV } & \text { = knowledge variable } \\
\text { CRV } & \text { = capital resources variable } \\
\text { ISV } & \text { = innovative services variable } \\
\text { SNCV } & \text { = social networks and cooperation variable }
\end{array}
$$

\subsection{Data Analysis}

The data used the internal factors (independence, knowledge); and the external factors (capital resources, innovative services, social networks and cooperation) that influenced the achievement of YAD. Internal factors in the form of independence means the ability to make their own decisions and take appropriate actions, the ability to solve problems and constraints, and also well-being managerial skills. Knowledge include the suitability of educational background, entrepreneurship education received, training and internships received, and also business experience has been over done. External factors include the initial capital resources support used, the customer service provided and the marketing technology used, the social networking and cooperation partners in running a business.

The data were processed using the Strength, Weaknesses, Opportunities, Threats (SWOT) analysis. SWOT analysis was amied to compare the internal factors (strength and weaknesses) within external factors (opportunities and threats) collectively as a basis for designing strategies and work programs. Determination of S, W, O, T obtained after obtaining the average value of each variables from the results of the questionnaire compilation. Internal factors will generate strengths and weaknesses through the Internal Factors Strategic Analysis (IFAS) matrix. The variables were categorized as strength if the average value is greater compared to the median value of the calculation scale, meanwhile the variables were classified as weakness if the average value is smaller compared to the median value of the calculation scale. External factors will generate opportunities and threats through the External Strategic Factors Analysis (EFAS) matrix. The variables were classified as opportunity if the average value is greater compared to the median value of the calculation scale, meanwhile the variables were classified as threat if the average value is smaller compared to the median value of the calculation scale.

\section{Results}

\subsection{Determination of Strengths, Weaknesses, Opportunities and Threats for Achievement of Youth Agripreneurship}

Based on the results of the SWOT analysis in determining the strengths, weaknesses,

\begin{tabular}{|c|c|c|}
\hline Internal Factors & Strengths (S) & Weaknesses (W) \\
\hline $\begin{array}{l}\text { Independence } \\
\text { Knowledge }\end{array}$ & $\begin{array}{l}\sqrt{ } \\
\sqrt{ }\end{array}$ & \\
\hline External Factors & Opportunities $(\mathrm{O})$ & Threats $(\mathrm{T})$ \\
\hline $\begin{array}{l}\text { Capital resources } \\
\text { Innovative services } \\
\text { Social networks and cooperation }\end{array}$ & $\sqrt{ }$ & $\begin{array}{l}\sqrt{ } \\
\sqrt{ }\end{array}$ \\
\hline
\end{tabular}
opportunities and threats of strategies for youth agripreneurship development (YAD) in Sumatra region can be seen in Table 3 .

Table 3. Determination of strengths, weaknesses, opportunities and threats to the strategy of YAD in Sumatra region

Table 3 showed that all variables in internal factors were classified as strengths, and not found variables of weakness. The variables of external factors were classified as opportunity found in capital resources, meanwhile the variables were classified as threat found in innovative services, and social networking and cooperation. 


\subsection{Determination of IFAS and EFAS Matrix for Youth Agripreneurship Development Strategy}

Based on the results of the IFAS matrix in determining the strategy of youth agripreneurship development (YAD) in Sumatra region can be presented in Table 4. The weights value is obtained from the level of interest each variable which the total weight for all internal factors is one. Meanwhile, the score was obtained from the average value of the questionnaire results for each variable. The results of the IFAS matrix showed that the difference in the weighted score between strengths and weaknesses found in the ordinate of 3.57 .

Table 4. The IFAS matrix for the strategy of YAD in Sumatra region

\begin{tabular}{lccc}
\hline Factors of Internal Strategic & Weight & Score & Weighted Score \\
\hline Strengths & & & \\
\hline Independence & 0.53 & 3.79 & 2.01 \\
Knowledge & 0.47 & 3.33 & 1.56 \\
Total score of strengths & 1.00 & & 3.57 \\
\hline Weaknesses & & & \\
$\quad$ None & 0.00 & 0.00 & 0.00 \\
Total score of weakness & 1.00 & & 3.57 \\
\hline Difference (strength - weakness) &
\end{tabular}

Based on the results of the EFAS matrix in determining the strategy for youth agripreneurship development (YAD) in Sumatra region can be presented in Table 5. The weight value is obtained from the importance level of each variable which the total weight value for all external factors is one. Meanwhile the score value is obtained from the average value of the questionnaire summary results for each variable. The results of the EFAS matrix showed that the difference in the weighted score between opportunities and threats found in the ordinate of -0.41 .

Table 5. The EFAS matrix for the strategies of YAD in Sumatra region

\begin{tabular}{lccc}
\hline Factors of External Strategic & Weight & Score & Weighted Score \\
\hline Opportunities & & & \\
\hline Capital Resource & 0.33 & 4.20 & 1.39 \\
Total score of opportunities & 0.33 & & 1.39 \\
\hline Threats & & & 0.72 \\
\hline Innovative services & 0.30 & 2.40 & 1.08 \\
$\quad$ Social networks and cooperation & 0.37 & 2.93 & -0.41 \\
Total score of threats & 0.67 & & \\
\hline Difference (opportunities - threats) & 1.00 & & \\
\hline
\end{tabular}

\subsection{Determination of the Position Matrix in SWOT}

Based on the IFAS and EFAS matrices, were obtained at two points of ordinate such as the first ordinate point with a difference of strength-weakness of 3.57 and the second ordinate point with a difference of opportunities-threats of -0.41 . The SWOT position matrix can be presented in Figure 1 . 


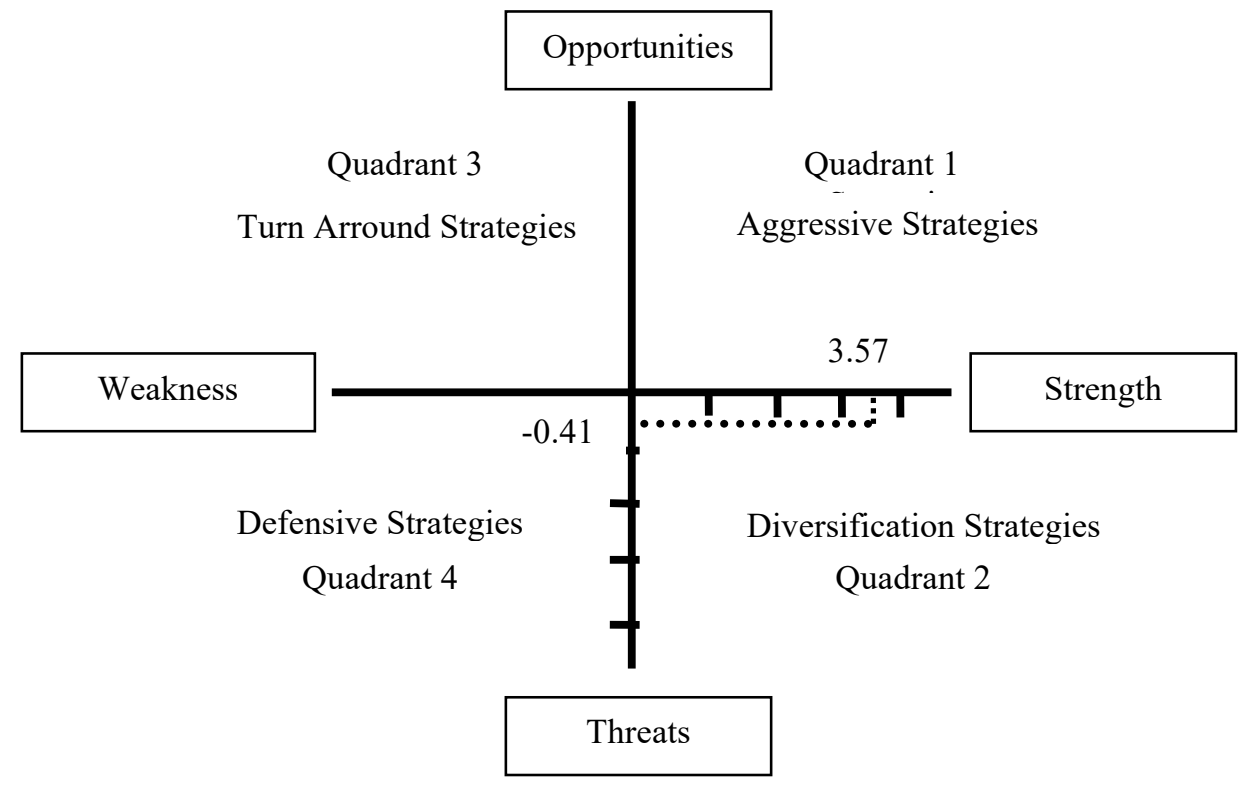

Figure 1. The SWOT position matrix for the strategy of youth agripreneurship development.

The SWOT position matrix for the strategy of YAD in Sumatra region was found in quadrant 2 or the diversification strategy. Despite facing various threats, youth agripreneurship still have strength from an internal perspective. The strategy should be applied by use the strength possessed to face and overcome the impact of the threat using the diversification strategy.

Based on the steps of the SWOT analysis, several strategies can be formulated using the SWOT matrix (Table 6).

Table 6. Strategies using the SWOT matrix

\begin{tabular}{|c|c|c|}
\hline $\mathrm{T}^{\mathrm{IFAS}}$ & $\begin{array}{l}\quad \text { STRENGTHS (S) } \\
\text { 1. Independence } \\
\text { 2. Knowledge }\end{array}$ & $\begin{array}{l}\text { WEAKNESSES (W) } \\
-\end{array}$ \\
\hline $\begin{array}{l}\text { OPPORTUNITIES }(\mathrm{O}) \\
\text { 1. capital resources }\end{array}$ & $\begin{array}{l}\text { S-O STRATEGY } \\
\text { 1. Increase financial managerial skills and } \\
\text { bookkeeping by training of financial } \\
\text { management }(\mathrm{S} 2,01) \\
\text { 2. Improve the ability to observe opportunities } \\
\text { and risks of using business capital }(\mathrm{S} 1, \mathrm{~S} 2 \text {, } \\
\text { O1) } \\
\text { 3. Dare to take risks in finding new sources of } \\
\text { capital for business development }(\mathrm{S} 1, \mathrm{O} 1)\end{array}$ & W-O STRATEGY \\
\hline \begin{tabular}{ll}
\multicolumn{1}{c}{ THREATS $(\mathrm{T})$} \\
1. & $\begin{array}{l}\text { Innovative services } \\
\text { 2. }\end{array}$ \\
$\begin{array}{l}\text { Social networking and } \\
\text { collaboration }\end{array}$
\end{tabular} & $\begin{array}{l}\text { S-T STRATEGY } \\
\text { 1. Increase knowledge and use of technology } \\
\text { based access industry } 4.0 \text { in customer service } \\
\text { and product marketing (S2, T1) } \\
\text { 2. Independence in increasing knowledge and } \\
\text { communication skills by participating in } \\
\text { training (S1, S2, T2) } \\
\text { 3. Establishing more intense cooperation with } \\
\text { business partners (S1, T2) } \\
\text { 4. Increasing promotion to various agencies } \\
\text { and companies to attract and establish } \\
\text { business cooperation (S1, S2, T2) }\end{array}$ & W-T STRATEGY \\
\hline
\end{tabular}




\section{Discussion and Conclusion}

The variables of internal factors were classified as strengths, and not found variables of weakness. It was all participants in youth entrepreneurs have a education background in agricultural science and are familiar with agricultural studies with the result that all internal factors have the fairly high value in overall. In addition, participants also have the ability to make decisions, solve problems, and make the most of all the resources available. Educational background was linear with the level of independence of youth entrepreneurs in developing self-potential by searching for information and interacting with educational institutions of YAD implementing. According to Karami and Agahi (2018) empowerment of agricultural entrepreneurs can be conducted by aggressive strategies such as training and entrepreneurial skills, development and technical, finding the source of ideas, using new technology, increasing access to financial resources, create exhibitions and conferences. Malta (2016) reported that the efforts to increase farmer independence in making decisions for the achievement of farming, namely the active search for information related to farming and interactions with agricultural instructors.

The variables of external factors were classified as opportunity found in capital resources, meanwhile the variables were classified as threat found in innovative services, and social networking and cooperation. Capital resources was categorized as opportunities because the source of capital used by youth agripreneurship from the government of Indonesia through the Ministry of Agriculture. It showed that the role of the government is greatly supportive to the program of YAD in Sumatra region. In contrast, innovative services and social networking as well as cooperation were classified as threats because YAD in Sumatra region still use innovative services include easy access to transportation and 24-hour communication services as well as the marketing technology used still uses social media such as facebook, instagram, telegram and tweeter. It requires improving the skills of the youth generation of farmers in utilizing information technology such as business partners in selling agricultural products based online. According to D'Silva et al. (2009) the agricultural sector has enormous potential and a growing business with full and active support from the government provides and greater opportunities for young agricultural entrepreneurs. Abdullah and Sulaiman (2013) reported that the influence factors of young generation to be entrepreneurs include family support, government support and promotion through carnivals and festivals. Agahi and Karami (2012) social capital management in society is product quality and attention to new product development and its relationship with awareness of the global market. Addo (2018) reported that the personal factors that affect the success of agricultural entrepreneurship performance, including (1) inspiration and decisions to start agricultural entrepreneurship, (2) learning, discovery and innovation, (3) planning and coordinating business activities, (4) building and maintain relationships between customers, suppliers and business partners.

The results of the IFAS matrix showed that the difference in the weighted score between strengths and weaknesses found in the ordinate of 3.57. It showed that the educational background of YAD in Sumatra region was linearly related to the level of independence in managing farming with the result that diversification strategy is needed (Figure 1). According to Malta (2016) the effect of formal education was positively correlated by $9.40 \%$ in increasing farmer independence for decision-making for farming success include activeness searching for information related to farming and interaction with the instructor. Ommani (2011) reported that higher technical knowledge of farmers have a score of 0.24 was classified as the strength factor in managing the agricultural system business. Hormiga et al. (2011) added that basic and advanced of skills in agricultural education were needed to support agripreneurship. Magagula and Tsvakirai (2019) also stated that the agricultural knowledge was significantly $(P<0.01)$ and has a positive effect on interest in participating for agripreneurship.

The results of the EFAS matrix showed that the difference in the weighted score between opportunities and threats found in the ordinate of -0.41 . It was due to the low access to information in managing farming which makes it difficult for youth agripreneurship to collaborate with business partners with the result that the diversification strategy is needed (Figure 1). According to Karami and Agahi (2018) the challenges of agricultural entrepreneurial empowerment could be caused by a lack of suitable markets for the products produced, a lack of required facilities, and a lack of useful skills training with the weighing score of $0.25 ; 0.18$ and 0.172, respectively. Sinyolo and Mudhara (2018) reported that the use of the entrepreneurial skills and abilities approach of farmers can be improve the food security of smallholders. 
The conclusion of this research such as strategy formulation can be conducted in the development of youth agripreneurship in Sumatra region by implementing the diversification strategy, such as 1) increasing knowledge and utilization of access to industry-based technology in customer service and product marketing; 2) independence in increasing knowledge and communication skills by attending training; 3) establish more intense cooperation with business partners; and 4) increasing promotion to various agencies and companies to attract and establish business cooperation.

\section{References}

Abdullah, A. A., \& Sulaiman, N. N. (2013). Factors that influence the interest of youths in agricultural entrepreneurship. International Journal of Business and Social Science, 4(3), 288-302.

Addo, L. K. (2018). Factors influencing agripreneurship and their role in agripreneurship performance among young graduate agripreneurs. International Journal of Environment, Agriculture and Biotechnology, 3(6), 2051-2066.

Agahi, H., \& Karami, S. (2012). Study of factors effecting social capital management and its impact on success of production cooperatives. Annals of Biological Research, 3(8), 4179-4188.

D'Silva, J. L., Shaffril, H. A. M., Uli, J., \& Samah, B. A. (2009). A review of contract farming and factors that impinge youths acceptance to contract farming. European Journal of Social Sciences, 11(2), 328-338.

Gulo, W., Harahap, N., \& Basri, A. H. H. (2018). The perspective of the young generation on food agriculture in the Moro'o Sub-district, West Nias District. Agrica Ekstensia, 12(1), 60-71.

Hormiga, E., Batista-Canino, R. M., \& Sánchez-Medina, A. (2011). The role of intellectual capital in the success of new ventures. International Entrepreneurship and Management Journal, 7(1), 71-92. doi:10.1007/s11365-010-0139-y.

Insani, F. R., Setiawan, I., \& Rasiska, S. (2018). Determinant of participation and role of young farmer in environmentally friendly agricultural development in Cisondari Village, Ciwidey District, Bandung Regency, West Java. Mimbar Agribisnis: Jurnal Pemikiran Masyarakat Ilmiah Berwawasan Agribisnis, 4(2), 153-168. doi:10.25157/ma.v4i2.1133.

Karami, S., \& Agahi, H. (2018). SWOT analysis of strategies for agricultural entrepreneurs empowerment. International Journal of Agricultural Management and Development, 8(2), 307320.

Langit, A A. I. D. S., \& Ayuningsasi, A. A. K. (2019). The influence of land area, labor, and capital on citrus farming production. E-Jurnal Ekonomi Pembangunan Universitas Udayana, 8(8), 17571788 .

Listiani, R., Setiadi, A., \& Santoso, S. I. (2019). Income analysis of rice production in Mlonggo District, Jepara Regency. Agrisocionomics: Jurnal Sosial Ekonomi Pertanian, 3(1), 50-58. doi:10.14710/agrisocionomics.v3i1.4018.

Maga, L., Ola, T. L., Batoa, H., \& Purwanti, R. E. (2016). The level of youth motivation in managing cocoa farming in Wapae Jaya Village, Tiworo Tengah Sub-district, Muna District. Sosio Agribisnis, 4(3), 1-28.

Magagula, B., \& Tsvakirai, C. Z. (2019). Youth perceptions of agriculture: influence of cognitive processes on participation in agripreneurship. Development in Practice, 30(2), 234-243. doi:10.1080/09614524.2019.1670138.

Malta, M. (2016). Factors related to farmer independence in decision making on sustainable agribusiness (a case study of farmers in Sukaharja Village, Bogor Regency). Cakrawala-Jurnal Humaniora, 16(1), 118-124. doi:10.31294/jc.v16i1.1281.

Mamondol, M. R. (2017). The using efficiency of labor and capital production factors in soybean farming at Pamona Village, Pamona Puselemba District, Poso Regency. Jurnal Envira, 2(2), 17. doi:10.31227/osf.io/gb3jk.

Ministry of Agriculture. (2018). Agricultural sector employment statistics for 2017-2018. Center For Agriculture Data and Information Systems, Ministry of Agriculture, Jakarta. Indonesia. p. 104.

Ommani, A. R. (2011). Strengths, weaknesses, opportunities and threats (SWOT) analysis for farming system businesses management: Case of wheat farmers of Shadervan District, Shoushtar Township, Iran. African Journal of Business Management, 5(22), 9448-9454. doi:10.5897/AJBM.9000528. 
Santoso, A. B. (2015). Effect of land use and subsidized fertilizer for national rice production. Jurnal Ilmu Pertanian Indonesia, 20(3), 208-212. doi:10.18343/jipi.20.3.208.

Sevilla, C. G. (2007). Research methods. Quezon City: Rex Printing Company.

Sihombing, F. N., Tampubolon, K., \& Juniarsih, T. (2020). Regression factors of rainfall, humidity, and rainy day on pepper yield and policy alternatives in North Sumatra. Agrinula: Jurnal Agroteknologi dan Perkebunan, 3(2), 73-83. doi:10.36490/agri.v3i2.102.

Sinyolo, S., \& Mudhara, M. (2018). The impact of entrepreneurial competencies on household food security among smallholder farmers in KwaZulu Natal, South Africa. Ecology of Food and Nutrition, 57(2), 71-93. doi:10.1080/03670244.2017.1416361.

Statistics of Indonesia. (2020). GDP contribution at current market prices, 2010-2020. Statistics Indonesia, Jakarta.

Suwarto. (2008). Land productivity and food crop farming costs in Gunung Kidul District. Jurnal Ekonomi Pembangunan: Kajian Masalah Ekonomi dan Pembangunan, 9(2), 168-183. doi:10.23917/jep.v9i2.1023.

Tampubolon, K., \& Sihombing, F. N. (2017). The effect of rainfall and rainy days on agricultural production and its relationship with GDP on current prices in Medan City. Jurnal Pembangunan Perkotaan, 5(1), 35-41.

Usman, U, \& Juliyani. (2018). The effect of land area,fertilizer and labor on the amount of rice production in Matang Baloi Village. Jurnal Ekonomi Pertanian Unimal, 1(1), 31-39. doi:10.29103/jepu.v1i1.501. 